\title{
Droughts in the Amazon: Identification, Characterization and Dynamical Mechanisms Associated
}

\section{Sérgio Rodrigo Quadros dos Santos ${ }^{1}$, Célia Campos Braga ${ }^{2}$, Clovis Angeli Sansigoloㄹ, Theomar Trindade de Araujo Tiburtino Neves ${ }^{3}$, Ana Paula Paes dos Santos ${ }^{1}$}

\author{
${ }^{1}$ National Institute for Space Research (INPE), São José dos Campos, SP, Brazil \\ ${ }^{2}$ Federal University of Campina Grande (UFCG), Campina Grande, PB, Brazil \\ ${ }^{3}$ Federal University of Pará Western Brazil (UFOPA), Santarém, Pa, Brazil \\ Email: sergiosanntos@yahoo.com.br
}

How to cite this paper: dos Santos, S.R.Q., Braga, C.C., Sansigolo, C.A., de Araujo Tiburtino Neves, T.T. and dos Santos, A.P.P. (2017) Droughts in the Amazon: Identification, Characterization and Dynamical Mechanisms Associated. American Journal of Climate Change, 6, 425-442.

https://doi.org/10.4236/ajcc.2017.62022

Received: April 14, 2017

Accepted: June 25, 2017

Published: June 28, 2017

Copyright $\odot 2017$ by authors and Scientific Research Publishing Inc. This work is licensed under the Creative Commons Attribution International License (CC BY 4.0).

http://creativecommons.org/licenses/by/4.0/

\begin{abstract}
In this study, we used the Standard Precipitation Index (SPI) to identify and to characterize the dry extreme events in the Amazon region. The results showed that the drought of 1998 was the most intense (SPI average equal to $-1.69)$ in the period from 1979 to 2014 . However, some papers have characterized the years 2005 and 2010 as the two largest droughts of the century. Thus, it was also carried out a comparative study of these droughts. The results showed that the drought 1998 was more intensive and extreme than the droughts of 2005 and 2010, although droughts of 2005 and 2010 lasted longer than 1998 due to oceanic and atmospheric conditions with influencing to cause greater social and economic impacts. Furthermore, it is suggested that the impact of the 2005 and 2010 droughts is a response from the dry occurred in 1993-1994 and 1997-1998.
\end{abstract}

\section{Keywords}

Precipitation Extremes, Dry, Rainy, SPI, Amazonia

\section{Introduction}

Studies showed that the Brazil is vulnerable to climate change, especially climatic extremes. The most vulnerable areas include the Amazon and Northeast Brazil, as demonstrated in recent studies [1]-[6]. In latest decades, the Amazon has experienced some extreme dry events; this attracted the attention of the scientists, not only because of the impact over local populations, but also because of the dry in the Amazon may have important impacts on the global climate [7] [8] [9]. 
When the drought is compared to other extreme recurring events, such as floods, it is recognized as a phenomenon that has equally adverse impacts, although they can be effectively mitigated. The occurrence of drought and its consequences may require some time to be perceived by the socio-economic systems, because they tend to evolve slowly. In addition, the extreme dry events in the Amazon may be associated with the following factors: 1) the occurrence of intense El Niño events; 2) anomalous warming of sea surface temperatures in the tropical North Atlantic during the austral winter-spring; or 3) a combination of these two effects [9]-[14].

One way to improve the studies on extreme dry events developed in this region would be through the application of techniques able to characterize and to define spatial and temporal potential patterns of these events. [15] proposed the Standard Precipitation Index (SPI) to quantify the precipitation deficit on different time scales. The versatility of SPI is in the simplicity of its calculation, furthermore, it identifies the dry events on several time scales (3, 6, 12 months, and so on). This helps to monitor the temporal dynamics of these events, i.e., the development and decline. Since it is a standardized index, the classification of the categories dry/rain can be used in any region of the world [16]. In addition, the SPI has an advantage over the other indices, e.g., Palmer Drought Severity Index, because it uses only monthly precipitation data, in other words, it is not necessary to use other meteorological variables to detect dry and rainy events [17]. Created in the United States of America, the SPI has been frequently used by researchers worldwide.

In this context, the present study has the following objectives: 1) identification and classification of the most intense drought events in the period from 1979 to 2014 using the SPI; 2) analyzing the temporal evolution of these dry events; 3) diagnosing the meteorological characteristics associated with them; 4) investigating the trends of dry and rainy events obtained by SPI in the study period.

\section{Data and Methodology}

\subsection{Study Area}

The study area is the Amazon region $\left(5^{\circ} \mathrm{N}\right.$ to $15^{\circ} \mathrm{S}$ and $74^{\circ} \mathrm{W}$ to $44^{\circ} \mathrm{W}$ ) (Figure 1). It is rich in biodiversity and fresh water, being important for the whole world, due its capacity to capture and hold carbon from the atmosphere. Moreover, the Amazon exerts a major role in South America climate by its effect on the hydrologic cycle [18].

\subsection{Precipitation Data Base}

In this research will be used four sets of precipitation data base. Two of these databases are based on precipitations interpolated values from surface observations provided by Global Precipitation Climatology Center (GPCC) [19] and Climate Prediction Center (CPC) [20]. The other database is based on observed precipitations that are combined with precipitation estimates generated from satellite data found in the Global Precipitation Climatology Project (GPCP) [21]. 


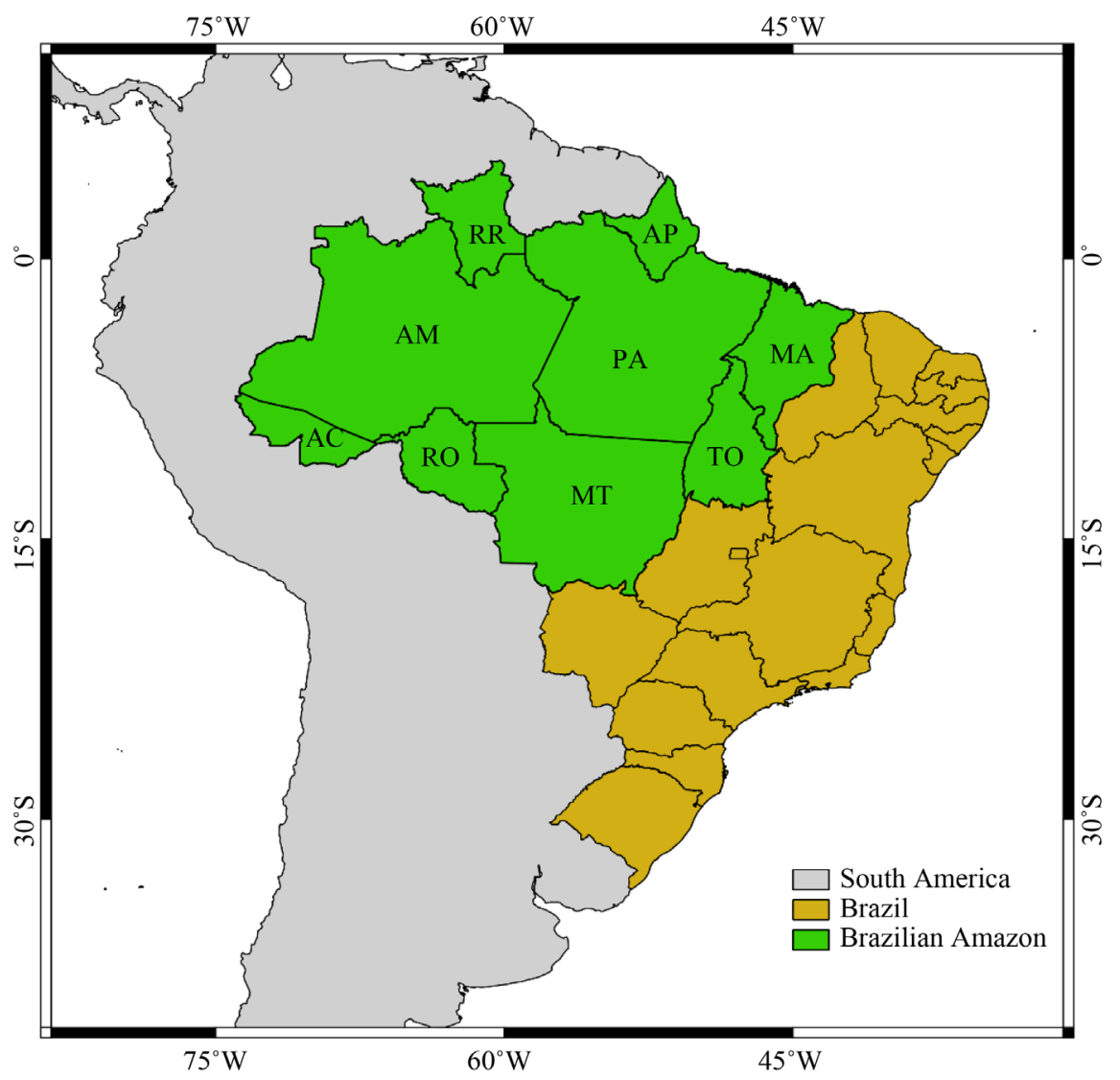

Figure 1. Location of the Amazon region.

The last set of data consists of reanalysis of the Era-Interim [22].

The purpose of using these data sets is to analyze the performance of GPCC data, once it consists of the largest continuum precipitation data series (1901 to present). In addition, the GPCC data is considered as a reference point in this study. Furthermore, is important to emphasize that all sets of rainfall data were interpolated to a spatial resolution of $2.5^{\circ} \times 2.5^{\circ}$ grid and adopted the period 1979-2014 as a common period between databases.

\subsection{Atmospheric and Oceanic Data}

In order to investigate the average and anomalous conditions of the atmosphere and oceans in extreme dry events, it was also used global atmospheric and ocean monthly data from reanalysis. The variables analysis was the zonal and meridional wind components, the vertical velocity and Sea Surface Temperature (SST). The atmospheric data were provided by NCEP/DOE AMIP-II Reanalysis (Reanalysis-2) [23], this dataset are available on global $2.5 \times 2.5$ grids and cover the period of 1979 to the present. The ocean data were provided by NOAA/ OAR/ESRL [24], this dataset is available on global $2 \times 2$ grids and cover the period of 1981 to the present.

\subsection{Standard Precipitation Index (SPI)}

The SPI calculation starts by determining a probability density function that de- 
scribes the temporal series. The Gamma Distribution (Equation (1)) it has good fit for continuous variables that have lower boundary of zero and no upper limit, for this reason it is widely used for the study of historical precipitation series [25].

$$
g(x)=\frac{x^{\alpha-1} * e^{\frac{-x}{\beta}}}{\beta^{\alpha} \Gamma(\alpha)} \text { to } x>0
$$

For $\alpha>0$ the shape parameter; $\beta>0$ the scale parameter; $x>0$, the quantity of rainfall $(\mathrm{mm})$ e $\Gamma(\alpha)$ the Gama function complete.

To estimate the parameters $\alpha$ and $\beta$ (Equations (1.1) and (1.2)) of the gamma distribution we used the method of maximum likelihood [26]:

$$
\begin{aligned}
& \alpha=\frac{1}{4 A}\left(1+\sqrt{1+\frac{4 A}{3}}\right) \text { and } \hat{\beta}=\frac{\bar{x}}{\hat{a}}, \bar{x} \text { is the average rainfall } \\
& A=\ln (\bar{x})-\frac{\sum \ln (x)}{n}, \text { " } n \text { " is the number of observations. }
\end{aligned}
$$

Thus the cumulative distribution is then transformed into normal probability distribution with mean zero and standard deviation one. Next, the cumulative probability of each monthly amount is estimated. Applies to this probability, the inverse normal function is to find the value of the SPI (Equation (1.3)). More information and/or consideration of this calculation can be found at [15] [16] [27] [28], among others.

$$
S P I=Z_{i}=\frac{P_{i}-\bar{P}_{i}}{\sigma_{i}}
$$

$P_{i}$ is the observed precipitation; $\bar{P}_{i}$ and $\sigma_{i}$, are the mean and standard deviation of the adjusted series, respectively.

The SPI categories are illustrated in Table 1; however, to simplify the interpretation of our results there was the adaptation of the classes as suggested by [15]. Not only droughts have been characterized, but also rainy seasons. One of the great advantages of this method is to standardize the analysis, which can be used to compare completely different regions, for example, regions with more humid climates with more arid ones.

\subsection{Mann-Kendall Test and Sen Method}

The non-parametric Mann-Kendall test shows that the presence of a monotonic tendency increasing or decreasing of the variable studied, then estimate the slope

Table 1. Dry and rainy classification based on the SPI [15].

\begin{tabular}{cc}
\hline SPI value & Category \\
\hline-1.5 or less & Extremely dry \\
-0.5 to -1.49 & Moderately dry \\
-0.49 to 0.49 & Near normal \\
1.49 to 0.5 & Moderately wet \\
1.5 or more & Extremely wet \\
\hline
\end{tabular}


and magnitude of the linear trend with the non-parametric Sen method [29] [30] [31]. In order to investigate the trends of dry and rain events at all time scales, it will be applied the non-parametric statistical Mann-Kendall test. [32] affirms that the Mann-Kendall test is the most appropriate method to analyze climatic changes in climatological series and also allows the detection and approximate location of the starting point of a given trend.

The test consists of the sum $t_{n}$ of the number of terms $m_{i}$ of the series, relative to the value $X_{i}$ whose previous terms $(j<i)$ are less than the same $\left(X_{j}<X_{i}\right)$, thus:

$$
t_{n}=\sum_{i=1}^{n} m_{i}
$$

According to [31], for series with a large number of terms $(N)$ and absence of trends (null hypothesis, Ho), $t_{n}$ will present normal distribution with mean $\left[E\left(t_{n}\right)\right]$ and variance $\left[\operatorname{Var}\left(t_{n}\right)\right]$. The test is calculated by:

$$
\begin{gathered}
E\left(t_{n}\right)=\frac{N(N-1)}{4} \\
\operatorname{Var}\left(t_{n}\right)=\frac{N(N-1)(2 N+5)}{72} \\
u(t)=\frac{\left(t_{n}-E\left(t_{n}\right)\right)}{\sqrt{\operatorname{Var}\left(t_{n}\right)}}
\end{gathered}
$$

If the value of $u(t)$ is less than -1.96 there is a significant trend at the $95 \%$ probability level in reducing the observed series values. When $u(t)$ is greater than 1.96, there are significant upward trends in the series.

However, the non-parametric method of Sen [33] [34] uses a linear model to estimate slope trend and residue variance being constant over time. Missing values are allowed and the data need not obey any specific distribution. In addition, the Sen method is not greatly affected by single die errors. It carried out the estimate of the true slope of the trend, assuming that it is linear, existing in a time series, making it possible to find the magnitude of this trend. This means that:

$$
f(t)=Q t-B
$$

where $Q$ is the slope and $B$ is a constant.

To obtain the slope estimate $Q$, we first calculate the slopes of all pairs and data.

$$
Q_{i}=\frac{x_{j}-x_{k}}{j-k}
$$

where $j>k$.

If there are $n$ values $x_{j}$ in the time series, we obtain $N=n(n-1) / 2$ slope estimates $Q_{i}$ Thus inclination estimated by the Sen method is the median of these $N$ values of $Q_{i}$. The $N$ values of $Q_{i}$ are ranked from lowest to highest, and the Sen estimate is:

$$
Q=Q_{\left[\frac{N+1}{2}\right]}, \text { if } N \text { is odd }
$$

or 


$$
Q=\frac{1}{2}\left(Q_{\left[\frac{N}{2}\right]}+Q_{\left[\frac{N+2}{2}\right]}\right), \text { if } N \text { is even. }
$$

To obtain an estimate of B in Equation (3), the $n$ values of the difference $X_{i}-Q t_{i}$ are calculated. A more detailed description for the $\mathrm{Z}$ Mann-Kendall statistical test, slope estimation $Q$ and the $B$ method constant can be found in [35].

\subsection{Case Study}

After the classification of the dry and rainy events through SPI, were selected the year that presented the lowest mean value in order to characterize the atmospheric and oceanic conditions in this extreme event. The variables mentioned in subsection 2.3 were analyzed through their respective anomalies, calculated from a climatological base of 35 years, comprising the period from 1981 to 2014. Maps for months January, April, July and October, representing the four seasons of the year, with the horizontal distribution of SST anomalies, vertical straight sections and SPI spatial distribution were elaborated to illustrate the zonal and meridional anomalous circulation along with the SPI spatial pattern.

In the vertical section of zonal wind, it was used the anomalies of the zonal component of the wind and the vertical velocity. The averages were calculated for the latitudinal range of $17^{\circ} \mathrm{S}$ to $5^{\circ} \mathrm{N}$, so that the latitude of $12^{\circ} \mathrm{S}$ is at the midpoint of the range. Similarly, the longitudinal range from $74^{\circ} \mathrm{W}$ to $44^{\circ} \mathrm{W}$ was chosen to obtain the mean values of the meridional wind component anomalies and of the vertical velocity represented in the vertical sections of meridional wind. This type of representation made it possible to diagnose areas with anomalous vertical movements in the atmosphere.

\section{Results.}

\subsection{Temporal Analysis of SPI's over the Amazon}

Evaluating the time series SPI's (Figure 2) at the GPCP, GPCC, CPC and Erainterim, on the Amazon Region, there has been a good time concordance between the SPI's series. Moreover, it can be noted that there is a difference phase between the maximum/minimum values of the SPI's between the databases. Additionally, the values observed in the ERA-Interim, in a few months, differ widely from those observed in the other databases. Note also that, in general, the three SPI scales the years 1983, 1984, 1991, 1992, 1993, 1997, 1998 and 2005 showed minimum values of SPI's. On the other hand, the years 1986, 1994, 2000, 2007 and 2009 showed the maximum values of the SPI's. According to data observed in Table 2 and Table 3, the highest and lowest SPI values are associated with ENSO or Atlantic Gradient events. In addition, it is observed that in the investigated period that the dry events were more intense than the rainy. This is associated with the positive phase of the Pacific Decadal Oscillation (PDO), since in this period (1979-2014) there was more frequent and intense El Niño (1982-83, 1986-87, 1990-94, 1997-98).

Considering the context of the tropical climate dynamics, it is known that the 


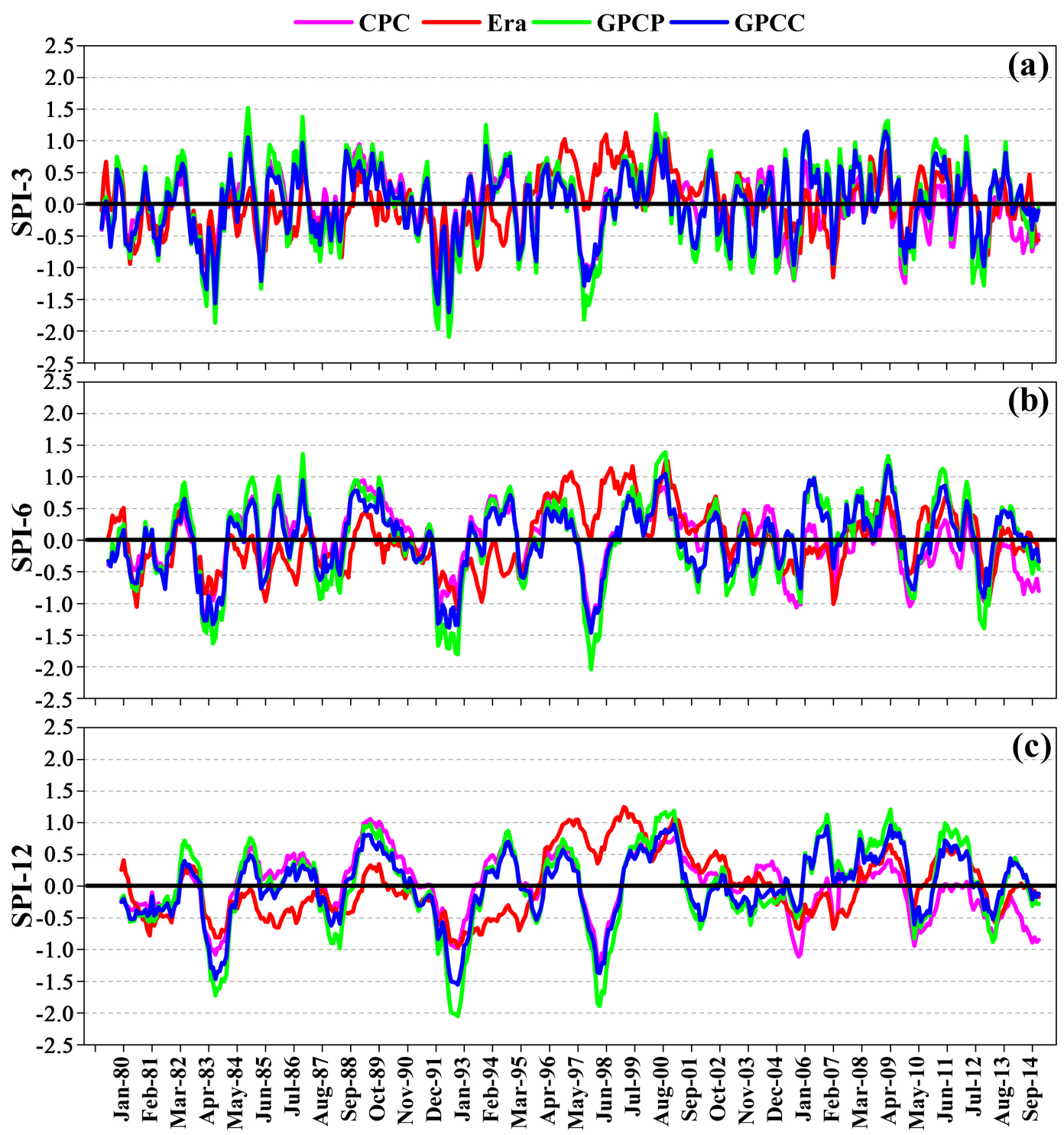

Time

Figure 2. Time series of the SPI-3 (a), SPI-6 (b) and SPI-12 (c) in the Amazon region $\left(5^{\circ} \mathrm{N}-15^{\circ} \mathrm{S}, 75^{\circ} \mathrm{W}-\right.$ $45^{\circ} \mathrm{W}$ ). Series calculated from the CPC databases (purple line), Era-Interim (red line), GPCP (green line) and GPCC (blue line) in the 1979-2014 period.

rainfall variability of the Amazon is modulated directly by: 1) the ocean-atmosphere large-scale patterns, associated with the ENSO cycle of the Pacific Ocean; 2) the phases of the meridional inter hemispheric temperature gradient anomalies of the sea surface (aSST) over the intertropical Atlantic Ocean, through significant changes in atmospheric circulation patterns associated with Walker and Hadley cells, interfering in the position and intensity of convective cloudiness bands South Atlantic Convergence Zone (SACZ) and Intertropical Convergence Zone (ITCZ) [36]-[42], therefore modulating the regional distribution of rainfall in the Amazon and consequently dry and rainy events.

Mann-Kendall and Sen Test of the SPI's in each database is presented in Table 4. The CPC showed an increasing tendency, of approximately 0.012 for SPI-3 
Table 2. Occurrence of El Niño and La Niña events during the period 1979 to 2014, and their respective intensities: weak event $\left(^{*}\right)$, moderate event $\left(^{* *}\right)$ and strong event $\left(^{* * *}\right)$. Source: Adapted from [1].

\begin{tabular}{cc}
\hline Occurrence of El Niño & Occurrence of La Niña \\
\hline $1979-1980^{*}$ & $1983-1984^{*}$ \\
$1982-1983^{* * *}$ & $1984-1985^{*}$ \\
$1986-1988^{* *}$ & $1988-1989^{* * *}$ \\
$1990-1993^{* * *}$ & $1995-1996^{*}$ \\
$1994-1995^{* *}$ & $1998-2001^{* *}$ \\
$1997-1998^{* * *}$ & $2007-2008^{* *}$ \\
$2002-2003^{* *}$ & \\
$2004-2005^{*}$ & \\
$2006-2007^{*}$ & \\
$2009-2010^{*}$ & \\
\hline
\end{tabular}

Table 3. Occurrence of events of the dipole pattern in the tropical Atlantic. Source: adapted from [1].

\begin{tabular}{cc}
\hline Positive Dipole & Negative Dipole \\
\hline $1966,1970,1978,1979$, & $1964,1965,1971,1972,1973$, \\
$1980,1981,1992,1997$ & $1974,1977,1985,1986,1989$ \\
\hline
\end{tabular}

Table 4. Values of $Z$ (trend) and Sig. (Statistical significance) resulting from the MannKendall test (M-K); and Q (magnitude) of the Sen method, for the mean SPI series on the Amazon region from 1979 to 2014.

\begin{tabular}{|c|c|c|c|}
\hline \multirow[t]{2}{*}{ GPCC } & \multicolumn{2}{|c|}{ M-K } & \multirow{2}{*}{$\begin{array}{c}\text { SEN } \\
\mathrm{Q}\end{array}$} \\
\hline & $\mathrm{Z}$ & Sig. \% & \\
\hline SPI-3 & 1.24 & - & 0.007 \\
\hline SPI-6 & 2.14 & 95 & 0.016 \\
\hline SPI-12 & 3.91 & 99.9 & 0.014 \\
\hline \multirow[t]{2}{*}{ GPCP } & \multicolumn{2}{|c|}{ M-K } & SEN \\
\hline & $\mathrm{Z}$ & Sig. \% & Q \\
\hline SPI-3 & 1.35 & - & 0.010 \\
\hline SPI-6 & 2.36 & 95 & 0.020 \\
\hline SPI-12 & 4.3 & 99.9 & 0.025 \\
\hline \multirow[t]{2}{*}{$\mathrm{CPC}$} & \multicolumn{2}{|c|}{ M-K } & SEN \\
\hline & $\mathrm{Z}$ & Sig. \% & Q \\
\hline SPI-3 & 1.84 & 90 & 0.010 \\
\hline SPI-6 & 2.52 & 95 & 0.013 \\
\hline SPI-12 & -4.10 & 99.9 & -0.011 \\
\hline \multirow[t]{2}{*}{ ERA-Interim } & \multicolumn{2}{|c|}{ M-K } & SEN \\
\hline & $\mathbf{Z}$ & Sig. \% & Q \\
\hline SPI-3 & -0.99 & - & -0.009 \\
\hline SPI-6 & -0.01 & - & -0.001 \\
\hline SPI-12 & 1.35 & - & 0.010 \\
\hline
\end{tabular}


and SPI-6, with statistical significance of $90 \%$ and $95 \%$, respectively. However, SPI-12 showed a decreasing trend with a statistical significance of $99.9 \%$. In Era-interim, there were decreasing trends (increasing) for SPI-3 and SPI-6 (SPI-12). However, none were statistically significant at $90 \%$ probability. On the other hand, the GPCC and GPCP presented increasing trends for dry and rainy events, but only at the 6 and 12 months temporal scales were significant at $90 \%$ probability. In GPCC (GPCP) the upward trend was approximately $0.007 ; 0.016$ and $0.014(0.010,0.020$ and 0.025$)$ for SPI-3, SPI-6 and SPI-12, respectively. Thus, the Amazon presented increasing trends of the dry and rainy events of short (SPI-3), mean (SPI-6) and long (SPI-12) duration in GPCC and GPCP databases. On the other hand, Era-Interim and CPC differed from the other databases because they presented decreasing trends of dry and rainy events of short and medium duration in the Era-interim and long duration in the CPC.

According to the analysis of Figure 2, it is observed that the GPCC satisfactory represent the SPI's values in the Amazon. Based on this, we performed a spatial analysis of SPI's obtained through the GPCC for the years 1998, 2005 and 2010. In 1998 it was observed the minimum amount of SPI's, and the years 2005 and 2010 were characterized as the two major droughts of the century [7] [8] [12]. Moreover, the oceanic and atmospheric conditions in large-scale associated with these dry events, the horizontal distribution of SST anomalies, the anomalous zonal and meridional circulation through vertical straight sections were also studied. These will be discussed below.

\subsection{General Aspects of Dry Events Observed 1998, 2005 and 2010 Characterized by the SPI-3, 6 and 12}

Positive SST anomalies over the Topical Pacific Ocean are observed in January 1998. In association with these anomalies are verified a strong descending anomalous movements of the studied region in zonal and meridional sections (Figure 3). In the following months, on the tropical Pacific, is noted the decrease (increase) of the areas with positive (negative) SST anomalies. In the Tropical Atlantic Ocean, especially in the northern part, there are positive SST anomalies. Additionally, there is the weakening of descending anomalous movements over the region, with the exception of the south portion. We highlight that the changes in the zonal/meridional circulation pattern associated with cell Walker/Hadley, disfavor/favor the convective activity in the Amazon region.

Figure 4 shows the spatial SPI resulting from the oceanic and atmospheric conditions mentioned above. Is noted that a large portion of the Amazon presents regions with extreme $(\mathrm{SPI}<-1.5)$ and moderate $(-0.5>\mathrm{SPI}>-1.49)$ dry events in January 1998. In April 1998, both the values and areas with dry events (SPI's negative) decrease considerably and, a small portion in the central part of the region is replaced by moderate rainfall events $(1.49>$ SPI $>0.5)$. A contrasting pattern between the north and south of the Amazon is observed in July 1998, where on the north side there is a predominance of moderate and extreme dry events and in the south side there is a predominance of moderate rain events. It 


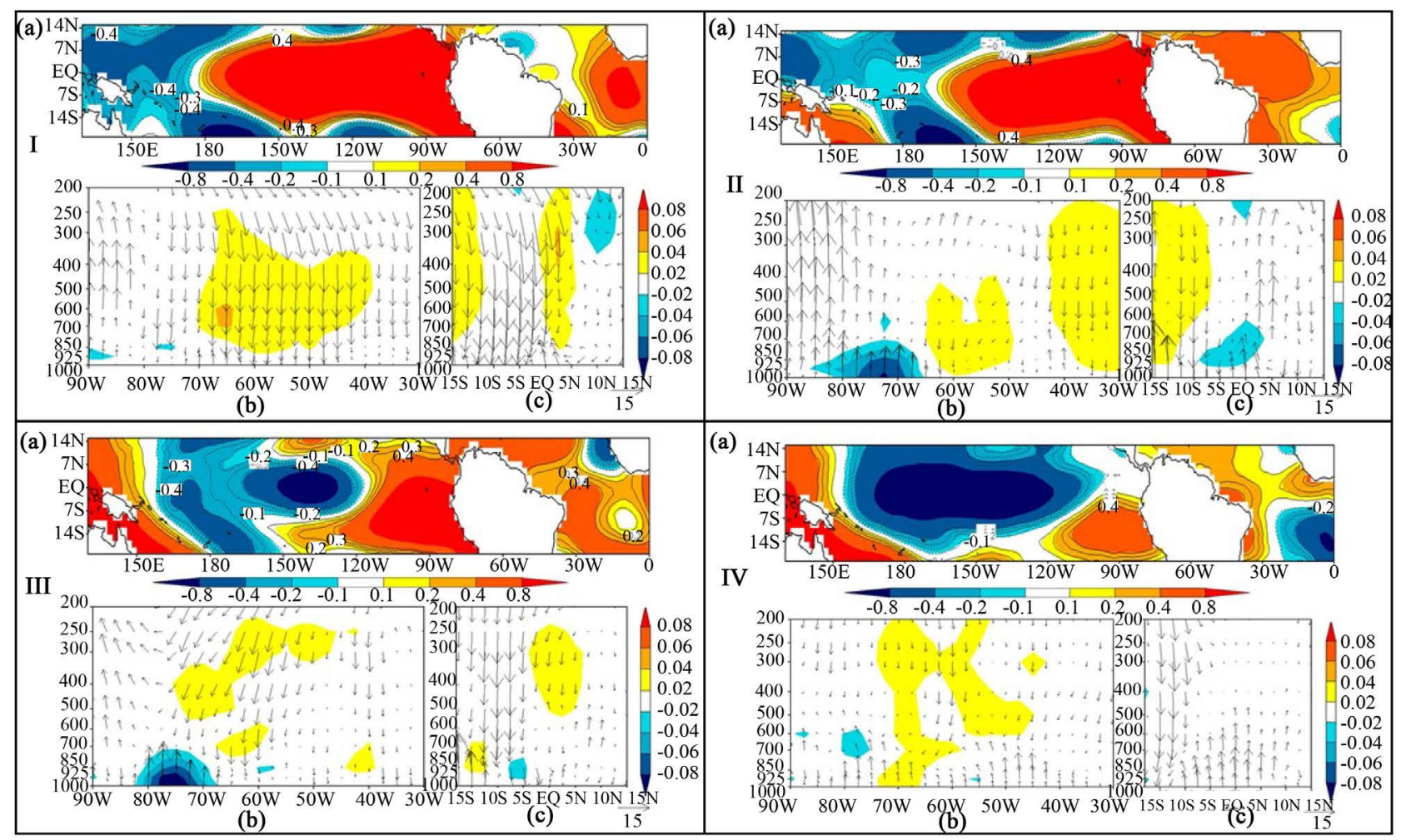

Figure 3. Monthly Anomalies January (I), April (II), July (III) and October (IV) in 1998 illustrated by: (a) horizontal distribution on the sea surface temperature $\left({ }^{\circ} \mathrm{C}\right)$; (b) vertical section of zonal wind (m.s. ${ }^{-1}$ ) and vertical velocity $(\mathrm{Pa} / \mathrm{s})$; (c) vertical section of meridional wind $\left(\mathrm{m} . s .^{-1}\right)$ and the vertical velocity $(\mathrm{Pa} / \mathrm{s})$. Anomalies were calculated considering the base period: 1981-2014.

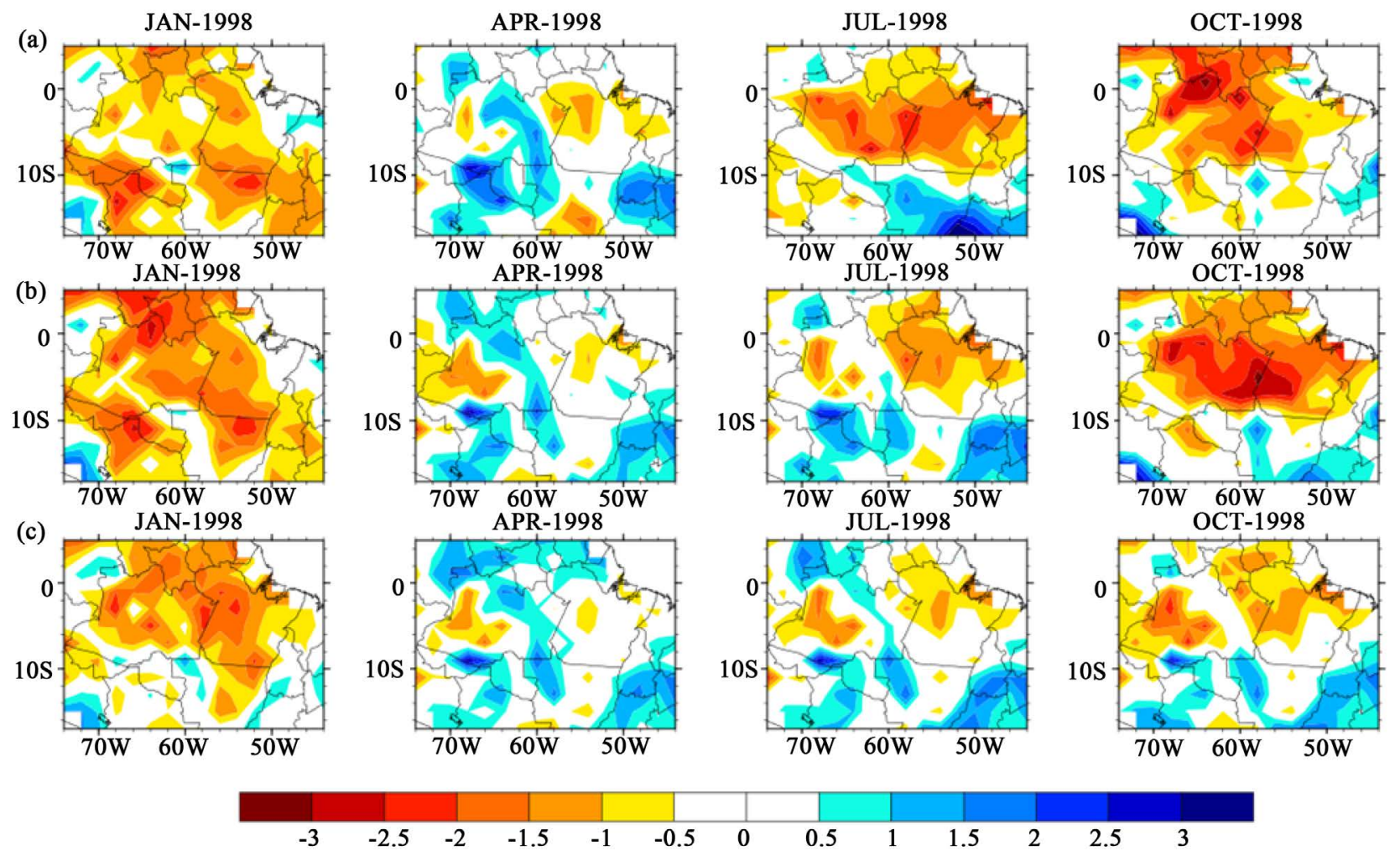

Figure 4. Spatio-Temporal distribution SPI-3 (a), SPI-6 (b) and SPI-12 (c) in January, April, July and October 1998. The SPI values were extracted from the rainfall data of GPCC considering the base period from 1979-2014. 
is also noted between north (moderate and extremes dry events) and south (moderate rain events) of SPI's in October 1998, however, SPI-3 and SPI-6 showed higher drought intensities on the north side of the region.

In 2005 (Figure 5), there were positive SST anomalies in a large portion of the tropical Pacific Ocean, with values up to $0.8^{\circ} \mathrm{C}$. However areas with positive SST anomaly decrease over time. In the Tropical North Atlantic Ocean, there was a predominance of positive SST anomalies throughout the year. Depending on the permanence, these oceanic conditions change the pattern of atmospheric zonal and meridional circulation resulting, generally, in an anomalous downward movement of air over the North and Northeast Brazil, generating a region of subsidence. When analyzing the zonal and meridional sections it is observed predominance of weak anomalous movements over the Amazon in the course of the months.

The spatial SPI resulting from oceanic and atmospheric conditions is presented in Figure 6. It can be noted that there is a strong contrast between the negative and positive values of SPI's in the Amazon in January, i.e., there are regions with both moderate dry events $(-0.5>$ SPI $>-1.49)$ and with moderate rainfall events $(1.49>\mathrm{SPI}>0.5)$. The western/central part of the region showed larger areas of moderate drought events, being more expressive in SPI- 6 and SPI-12 (Figure 6(b) and Figure 6(c)). These areas increase in July, being more expressive in SPI-3 where it is possible to observe extreme dry events (SPI < -1.5) (Figure 6(a)). Areas with dry moderate events enhance even further, however, on the SPI-3, there is a shift of the negative values of SPI's to the eastern

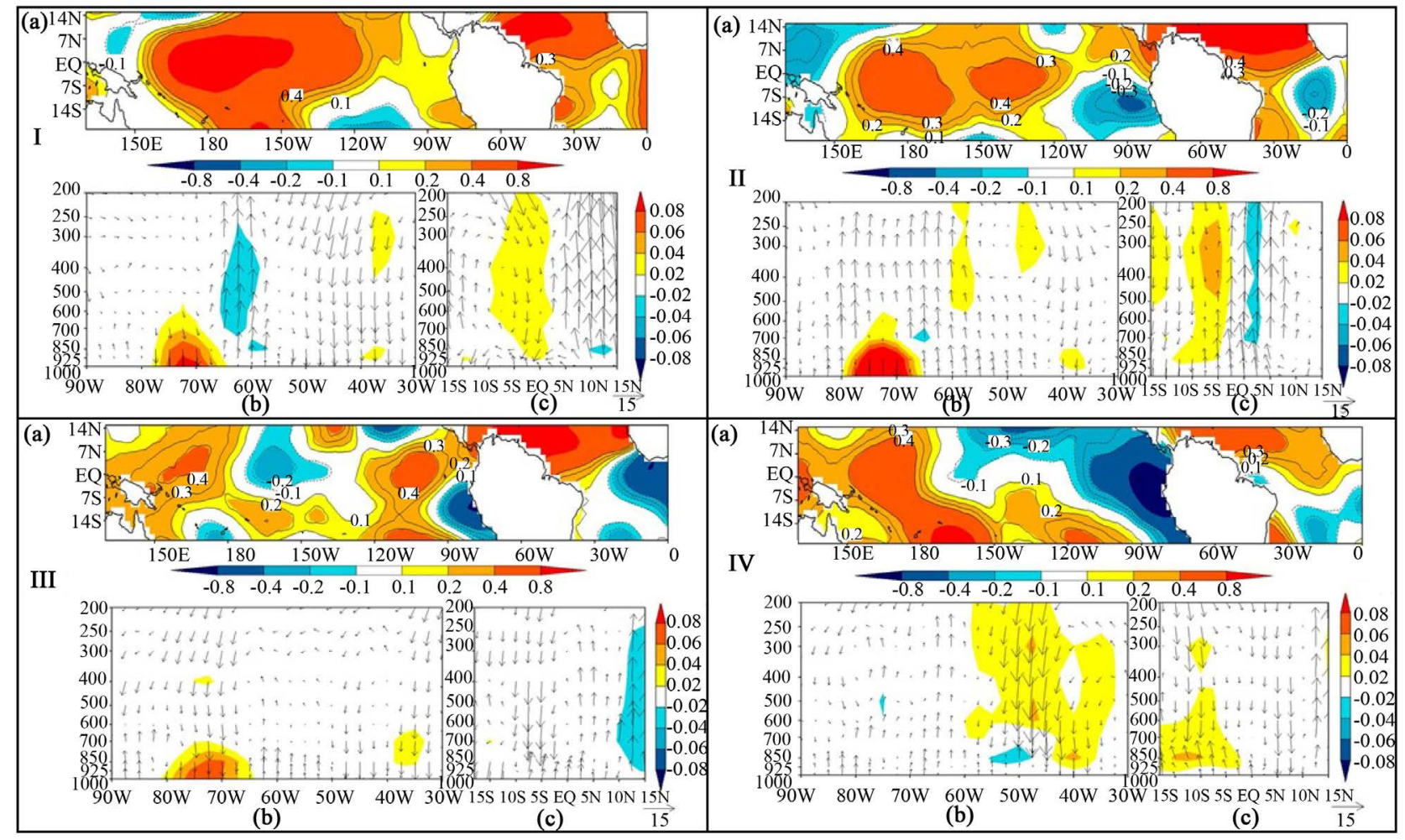

Figure 5. As in Figure 3, however, for the year 2005. 


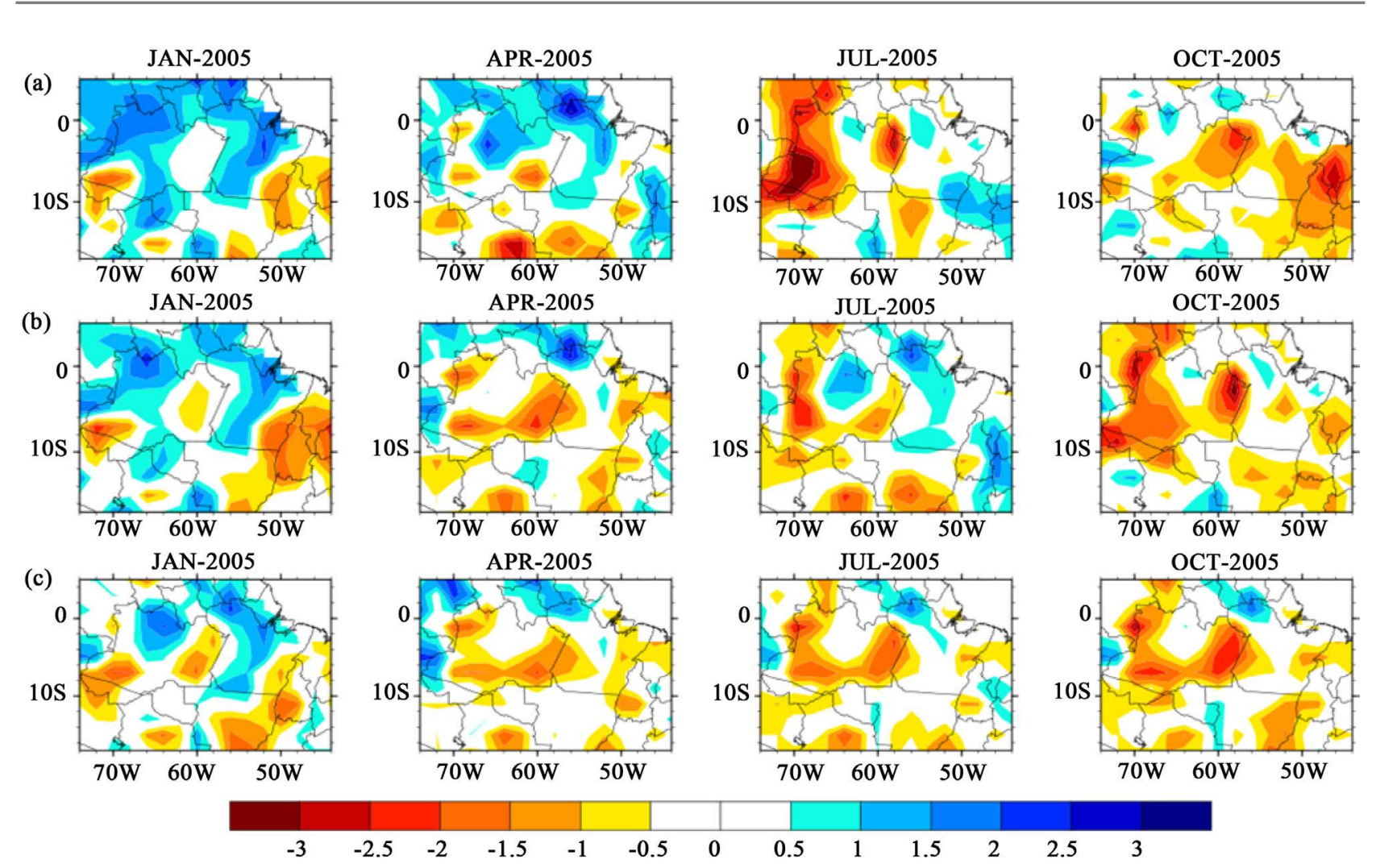

Figure 6. As in Figure 4, however, for the year 2005.

part of the Region in October. It is emphasized that the SPI-3 indicates the evolution of a short-term drought and rainfall events, allowing observe if there was mitigation or aggravation of drought or rainy conditions. The SPI- 6 and SPI-12 months, on the other hand, enable to, both at the beginning, middle and at the end of drought and rainfall events. Determine the medium and long-term impacts and regions affected by drought or rain.

In 2010 (Figure 7), the anomalies pattern of SST and zonal and meridional sections was not differ much from 2005. We emphasize that this year was the anomalous warming of the tropical north Atlantic, with SST anomalies greater than $0.8^{\circ} \mathrm{C}$. In addition, there is predominance of anomalous moderate downward movements in the course of months over the South portion and between $40^{\circ} \mathrm{W}$ and $60^{\circ} \mathrm{W}$.

For these oceanic and atmospheric conditions the Figure 8 presents the spatial SPI. In general, january presented moderate rainfall events $(1.49>$ SPI $>0.5)$ by the SPI-3 and SPI- 6 for the state of Pará (eastern Amazon) and in the northeastern portion of Mato Grosso State. In southwestern Amazon, there is moderate drought events $(-0.5>$ SPI $>-1.49)$, being more intense in the SPI-12. The Amazon (with the exception of the northwest portion) showed extreme and moderate dry events (SPI <-1.5) in April, however for the SPI-6 and SPI-12 we observed small regions in the Amazon with moderate rainfall events. The drought areas observed in the southern Amazon are so intense in July by SPI-6 as in April by SPI-3. The Amazon presents moderate and extreme drought 


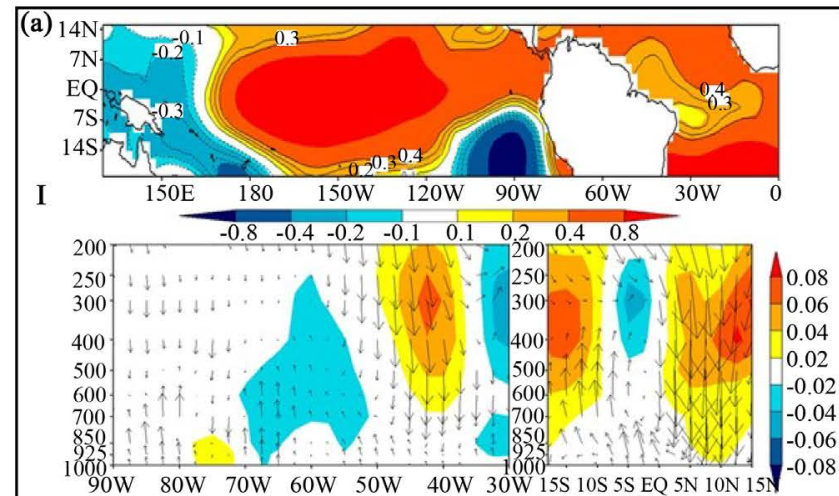

(b)

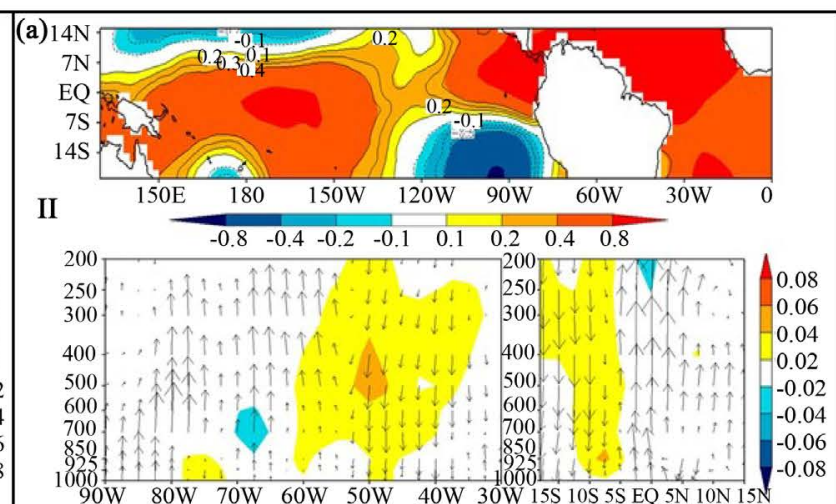

(b)

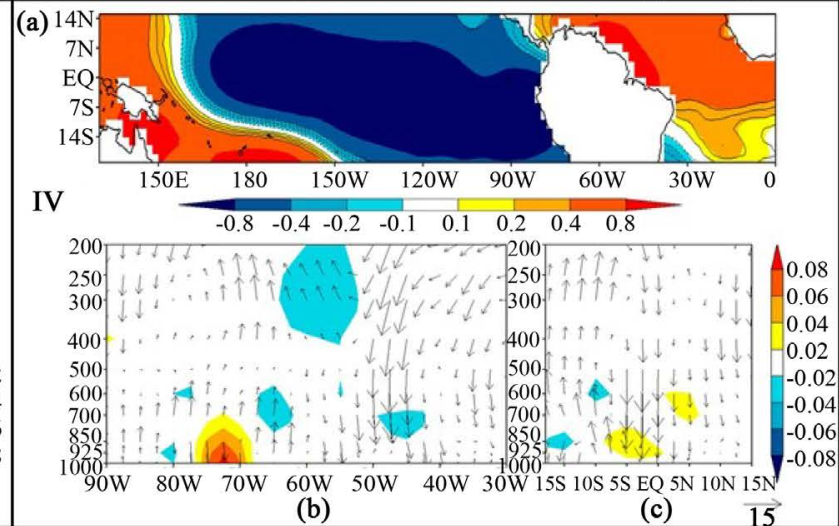

Figure 7. As in Figure 3, however for the year 2010.
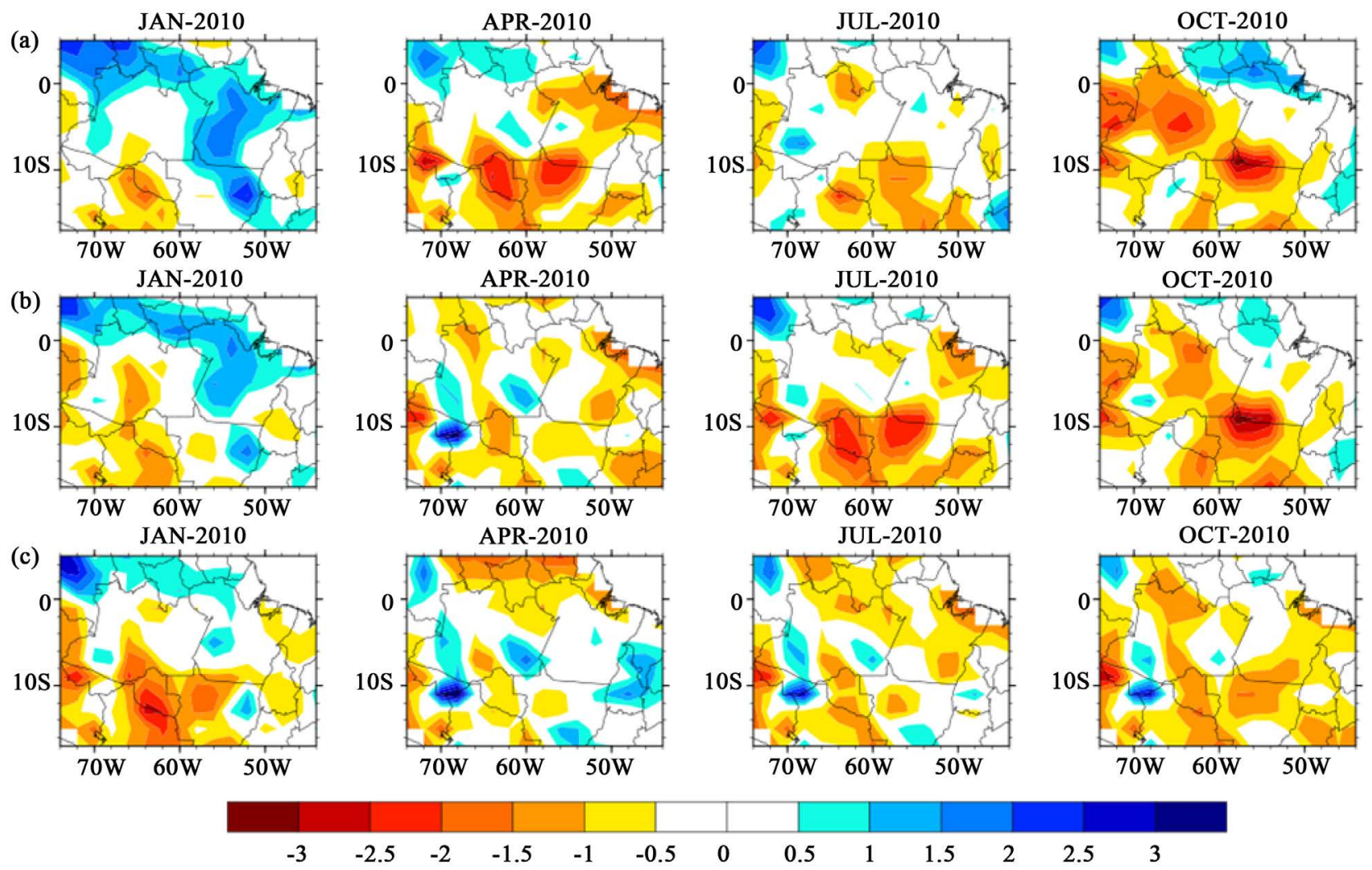

$\begin{array}{llllll}0.5 & 1 & 1.5 & 2 & 2.5 & 3\end{array}$

Figure 8. As in Figure 4, however, for the year 2010. 
events by SPI-3 and SPI- 6 in October. As noted previously, the SPI-3 has a higher outlier in their values, because this scale represents the dry and rainy events in the short term scale. The SPI- 6 and SPI-12, in turn, have less outlier values, as they represent dry and rainy events in the medium and long term, respectively.

Drought events in 1998, 2005 and 2010 presented similar characteristics in the Tropical Pacific Ocean, with positive SST anomalies, followed by a transition to negative anomalies. The three extreme events were also marked by positive SST anomalies in the North Tropical Atlantic, contributing to the establishment of a meridional local circulation (Hadley cell), with vertical upward movement over the North Atlantic and downward vertical movement (subsidence) on the Amazon, cloud formation was inhibited by this pattern. The combination of the positive SST anomalies observed in the Tropical Atlantic North and the Tropical Pacific Ocean reinforces the subsidence conditions on the Amazon are unfavorable to the occurrence of precipitation. The difference between the extreme drought events in 1998 for the 2005 and 2010 droughts was the action of both cells, Walker in the Pacific and Hadley in the North Atlantic, acting together in early 1998, this pattern intensified negative SPI values observed this year.

In terms of evolution of the spatial pattern of these events, it was noted that the drought of 1998 was the most intense in much of the Amazon, but over the months this intensity decreased along with its area of coverage. On the other hand, the droughts of 2005 and 2010 were more persistent than the one of 1998, due to the oceanic and atmospheric conditions that favored the persistence of the same ones, generating greater socioeconomic impacts as highlighted by [43] and [44].

In addition, it is suggested that the impact of the droughts of 2005 and 2010 be a response to the droughts of 1993-1994 and 1997-1998, despite normal rainfall in subsequent years, drought conditions in the 1990s were so severe that the floret was unable to fully recover. In agreement with this analysis, [44] emphasize that the extreme drought events continue at a time interval of 5 to 10 years, large areas of the Amazon will be lost florets given that the effects of drought are persistent and forest recovery is very slow.

Moreover, although these three years have been characterized as dry in the Amazon, it was noted that some regions showed moderate rainfall events (1.49> SPI $>0.5$ ), emphasizing the versatility of SPI to identify spatially and temporally dry or rainy events in their different time.

\section{Conclusions}

In the last decades, extreme rain and dry events have occurred in the Amazon Region and these events have been increasingly studied due to the impacts they cause in socioeconomic and environmental activities. In this regard, numerous studies have been made to quantify and characterize such events, and propose mitigation and adaptation strategies. Thus, in this study, they were characterized dry and rainy events at different time scales in the Amazon in the current climate (1979-2014). 
The temporal series of SPI-3, SPI-6 and SPI-12 in the GPCP, GPCC, CPC and Era-interim, on the Amazon Region presented a good temporal concordance between them in the period from 1979 to 2014. In the three SPI scales, the years 1983, 1984, 1991, 1992, 1993, 1997, 1998 and 2005 were characterized as dry. On the other hand, the years 1986, 1994, 2000, 2007 and 2009 were characterized as rainy. It was also found that dry events were more intense than the rainy during the study period. In addition, significant upward trends were observed for the dry and rainy events of short (SPI-3), mean (SPI-6) and long (SPI-12) duration which were observed in GPCC and GPCP databases. However, Era-Interim and CPC differed from the other databases because they presented decreasing trends in dry and rainy events of short and medium duration in the Era-interim and long duration in CPC.

In the historical context of droughts in the Amazon, some research evidences of the droughts of 2005 and 2010 were the two largest droughts of the century, showing similarities in terms of impacts. However, the distributions of rainfall deficits were different in the Amazon. However, when evaluating extreme dry and rainy events using SPI, it was evidenced that the lowest SPI values were observed in 1998, characterizing it as the most extreme dry event. The intensity of this extreme dry event decreases along with their area over the months. On the other hand, the eastern and southern regions of the Amazon, which were the hardest hit by the 2005 and 2010 droughts, remained with negative SPI values for a long time, evidencing that the impacts of the droughts of 2005 and 2010 were greater due to their persistence, when compared to the 1998 drought. In addition, extreme drought events observed in 1998, 2005 and 2010 were caused by the large-scale atmospheric circulation patterns forced by the positive SST anomalies in the Tropilcal Pacific and the North Tropical Atlantic.

The results found may provide subsidies to operational centers through knowledge of the temporal dynamics of these events, allowing preventive measures to be taken to minimize impacts caused by severe weather phenomena.

\section{Acknowledgements}

The first author is grateful to the Program of Graduate Studies in Meteorology of the National Spatial Research Institute (INPE) for granting CNPq doctoral fellowship and together with the other authors, thanks GPCC, GPCP, Era-Interim, CPC and NCEP/NCAR for the given data.

\section{References}

[1] Santos, S.R.Q., Braga, C.C., Sansigolo, C.A. and Santos, A.P.P. (2017) Determination of Homogeneous Precipitation Regions of the Standardized Precipitation Index (SPI) in the Eastern Amazon. Revista Brasileira de Meteorologia, 32, 111-122. https://doi.org/10.1590/0102-778632120160013

[2] Santos, S.R.Q., Sansigolo, C.A., Neves, T.T.D.A.T., Campos, T.L.D.O.B. and Santos, A.P.P. (2017) Frequency of Extreme Dry and Rain Events in Amazon Using Different Precipitation Data Bases. Revista Brasileira de Geografia Física, 10, 468-478. https://doi.org/10.5935/1984-2295.20170029 
[3] Aragão, L.E.O.C., Poulter, B., Barlow, J.B., Anderson, L.O., Malhi, Y., Saatchi, S., et al. (2014) Environmental Change and the Carbon Balance of Amazonian Forests. Biological Reviews, 89, 913-931. https://doi.org/10.1111/brv.12088

[4] Nobre, A.D. (2014) The Future Climate of Amazonia. São José dos Campos.

[5] Coe, M.T., Marthews, T.R., Costa, M.H., Galbraith, D.R., Greenglass, N.L., Imbu-zeiro, H.M.A., et al. (2013) Deforestation and Climate Feedbacks Threaten the Eco-Logical Integrity of South-Southeastern Amazonia. Philosophical Transactions of the Royal Society of London B: Biological Sciences, 368, Article ID: 20120155. https://doi.org/10.1098/rstb.2012.0155

[6] Gatti, L.V., Gloor, M., Miller, J.B., Doughty, C.E., Malhi, Y., Domingues, L.G., et al. (2014) Drought Sensitivity of Amazonian Carbon Balance Revealed by Atmospheric Measurements. Nature, 506, 76-80. https://doi.org/10.1038/nature12957

[7] Marengo, J.A., Nobre, C.A., Tomasella, J., Oyama, M.D., Sampaio de Oliveira, G., De Oliveira, R. and Brown, I.F. (2008) The Drought of Amazonia in 2005. Journal of Climate, 21, 495-516. https://doi.org/10.1175/2007JCLI1600.1

[8] Marengo, J.A., Tomasella, J., Alves, L.M., Soares, W.R. and Rodriguez, D.A. (2011) The Drought of 2010 in the Context of Historical Droughts in the Amazon Region. Geophysical Research Letters, 38. https://doi.org/10.1029/2011GL047436

[9] Coelho, C.A., Cavalcanti, I.A., Costa, S., Freitas, S.R., Ito, E.R., Luz, G. and Pezza, A.B. (2012) Climate Diagnostics of Three Major Drought Events in the Amazon and Illustrations of Their Seasonal Precipitation Predictions. Meteorological Applications, 19, 237-255. https://doi.org/10.1002/met.1324

[10] Di Mauro, G., Bonaccorso, G.B., Cancelliere, A. and Rossi, G. (2008) Use of NAO Index to Improve Drought Forecasting in the Mediterranean Area: Application to Sicily Region. Options Méditerranéennes Série A: Séminaires Méditerranéens, 80.

[11] Santos, S.R.Q.D., Silva, R.B.C.D., Barreto, P.N., Nunes, H.G.G., Rodrigues, R.D.S. and Campos, T.L.D.O.B. (2011) Thermal and Hydrologic Regime to Soil at Tropical Forest Area in Year of El Niño and La Niña, Caxiuanã-PA: A Case Study. Revista Brasileira de Meteorologia, 26, 367-374. https://doi.org/10.1590/S0102-77862011000300004

[12] Marengo, J.A. and Espinoza, J.C. (2015) Extreme Seasonal Droughts and Floods in Amazonia: Causes, Trends and Impacts. International Journal of Climatology, 36, 1033-1050. https://doi.org/10.1002/joc.4420

[13] Cavalcanti, I.F.A. (2012) Large Scale and Synoptic Features Associated with Extreme Precipitation over South America: A Review and Case Studies for the First Decade of the 21st Century. Atmospheric Research, 118, 27-40.

[14] Campos, T.L.D.O.B., Da Mota, M.A.S. and Dos Santos, S.R.Q. (2015) Extreme Precipitation Events in Belém-Pará: A Historical Review of Newspaper Articles. Revista Ambiente \& Água, 10, 182.

[15] McKee, T., Doesken, N. and Kleist, J. (1993) The Relationships of Drought Frequency and Duration to Time Scales. In: Conference on Applied Climatology, 8, Proceeding, American Meteorological Society, Boston, 233-236.

[16] Hayes, M. (2000) Revisiting the SPI: Clarifying the Process. Drought Network News, 12, 13-14.

[17] Guttman, N.B. (1998) Comparing the Palmer Drought Index and the Standardized Precipitation Index. Journal of American Water Resource Association, 34, 113-121. https://doi.org/10.1111/j.1752-1688.1998.tb05964.x

[18] Marengo, J.A., Chou, S.C., Torres, R.R., Giarolla, A., Alves, L.M. and Lyra, A. (2014) Climate Change in Central and South America: Recent Trends, Future Projections, 
and Impacts on Regional Agriculture.

https://cgspace.cgiar.org/rest/bitstreams/33625/retrieve

[19] Rudolf, B. and Schneider, U. (2005) Calculation of Gridded Precipitation Data for the Global Land-Surface Using in-Situ Gauge Observations. Proceedings of the 2nd Workshop of the International Precipitation Working Group IPWG, Monterey, October 2004, 231-247.

[20] Silva, V.B., Kousky, V.E., Shi, W. and Higgins, R.W. (2007) An Improved Gridded Historical Daily Precipitation Analysis for Brazil. Journal of Hydrometeorology, 8, 847-861. https://doi.org/10.1175/JHM598.1

[21] Huffman, G.J., Adler, R.F., Morrissey, M.M., Bolvin, D.T., Curtis, S., Joyce, R. and Susskind, J. (2001) Global Precipitation at One-Degree Daily Resolution from Multi-Satellite Observations. Journal of Hydrometeorology, 2, 36-50. https://doi.org/10.1175/1525-7541(2001)002<0036:GPAODD>2.0.CO;2

[22] Simmmons, A.S., Uppala, S., Dee, D. and Kobayashi, S. (2007) ERA-Interim: New ECMWF Reanalysis Products from 1989 Onwards. ECMWF Newsletter, 110, 25-35.

[23] Kanamitsu, M., Ebisuzaki, W., Woollen, J., Yang, S.K., Hnilo, J.J., Fiorino, M. and Potter, G.L. (2002) Ncep-doe amip-ii Reanalysis (r-2). Bulletin of the American Meteorological Society, 83, 1631-1643. https://doi.org/10.1175/BAMS-83-11-1631

[24] Huang, B., Thorne, P., Smith, T., Liu, W., Lawrimore, J., Banzon, V., Zhang, H., Peterson, T. and Menne, M. (2015) Further Exploring and Quantifying Uncertainties for Extended Reconstructed Sea Surface Temperature (ERSST) Version 4 (v4). Journal of Climate, 29, 3119-3142. https://doi.org/10.1175/JCLI-D-15-0430.1

[25] Wilks, D.S. (2006) Statistical Methods in the Atmospheric Sciences. 2nd Edition, Elsevier Science \& Technology Books, San Diego.

[26] Thom, H.C.S.A. (1958) Note on the Gamma Distribution. Monthly Weather Review, 86, 117-122. https://doi.org/10.1175/1520-0493(1958)086<0117:ANOTGD>2.0.CO;2

[27] Sansigolo, C.A. (2004) Comparative Performance Analysis of the Palmer Drought Severity Index (PDSI) and the Standardized Precipitation Index (SPI) in Piracicaba, São Paulo, Brazil (1917-2001). Revista Brasileira de Meteorologia, 19, 237-242.

[28] Santos, S.R.Q., Braga, C.C., Dos Santos, A.P.P., Campos, T.L.D.O.B. and De Brito, J.I.B. (2014) Classification of Extreme Precipitation Events in Multiple Time Scales in Belém, PA: Using the Standardized Precipitation Index. Revista Brasileira de Geografia Física, 7, 628-635.

[29] Santos, A.P.P., Aragão, M.R.D.S., Correia, M.D.F., Santos, S.R.Q.D., Silva, F.D.D.S. and Araújo, H.A.D. (2016) Precipitation in Salvador City: Temporal Variability and Classification in Quantis. Revista Brasileira de Meteorologia, 31, 454-467. https://doi.org/10.1590/0102-778631231420150048

[30] Blain, G.C. (2010) Tendências e variações climáticas em séries anuais de precipitação pluvial do Estado de São Paulo. Bragantia, 69, 765-770. https://doi.org/10.1590/S0006-87052010000300031

[31] Sneyers, R. (1975) Sur lànalyse statistique des séries d.òbservations. Organisation Météorologique Mondial, Genève.

[32] Goossens, C. and Berger, A. (1986) Annual and Seasonal Climatic Variations over the Northern Hemisphere and Europe during the Last Century. Annales Geophysicae, 4, 385-400.

[33] Sen, P.K. (1968) Estimates of the Regression Coefficient Based on Kend-All's Tau. Journal of the American Statistical Association, 63, 1379-1389. https://doi.org/10.1080/01621459.1968.10480934 
[34] Gilbert, R.O. (1987) Statistical Methods for Environmental Pollution Monitoring. Van Nostrand Rienhold Company, New York, 320.

[35] Salmi, T., Määttä, A., Anttila, P., Ruoho-Airola, T. and Amnell, T. (2002) Detecting Trends of Annual Values of Atmospheric Pollutants by the Mann-Kendall Test and Sen's Slope Estimates-The Excel Template Application MAKESENS. Helsinki (Publications on Air Quality No. 31, Report Code FMI-AQ-31).

[36] Nobre, P. and Shukla, J. (1996) Variations of Sea Surface Temperature, Wind Stress, and Rainfall over the Tropical Atlantic and South American. Journal of Climate, $\mathbf{9}$, 2464-2479. https://doi.org/10.1175/1520-0442(1996)009<2464:VOSSTW>2.0.CO;2

[37] Souza, E.B., Kayano, M.T., Tota, J., Pezzi, L., Fisch, G. and Nobre, C. (2000) On the Influences of the El Niño, La niña and Atlantic Dipole Paterni on the Amazonian Rainfall during 1960-1998. Acta Amazonica, 30, 305-318.

https://doi.org/10.1590/1809-43922000302318

[38] Molion, L.C.B. and Bernardo, S.D.O. (2002) A Review of the Dynamics of Rainfall in Northeast Brazil. Revista Brasileira de Meteorologia, 17, 1-10.

[39] Souza, E.B.D., Kayano, M.T. and Ambrizzi, T. (2005) Intraseasonal and Submonthly Variability over the Eastern Amazon and Northeast Brazil during the Autumn Rainy Season. Theoretical and Applied Climatology, 81, 177-191. https://doi.org/10.1007/s00704-004-0081-4

[40] Souza, E.B.D., Lopes, M.N., Da Rocha, E.J., Souza, J.R.S., Cunha, A.C.D., Silva, R.R.D. and Guimarães, P.L. (2009) Seasonal Precipitation in Eastern Amazon during Rainy Season: Regional Observations and RegCM3 Simulations. Revista Brasileira de Meteorologia, 24, 11-124.

[41] Santos, S.R.Q., Braga, C.C., Campos, T.L.D.O.B., de Brito, J.I.B. and Santos, A.P.P. (2014) Variability of Rainfall in the State of Pará through Principal Component Analysis. Revista Brasileira de Geografia Física, 7, 615-627.

[42] Kayano, M.T., Andreoli, R.V. and Ferreira de Souza, R.A. (2013) Relations between ENSO and the South Atlantic SST Modes and Their Effects on the South American Rainfall. International Journal of Climatology, 33, 2008-2023. https://doi.org/10.1002/joc.3569

[43] Brown, I.F., Schroeder, W., Setzer, A., Maldonado, M., Pantoja, N., Duarte, A. and Marengo, J. (2006) Fires in Rain Forests of Southwestern Amazonia: Multi-National Satellite Imagery for Monitoring and for Informing the Public. EOS Trans, 87, 253264. https://doi.org/10.1029/2006EO260001

[44] Saatchi, S., Asefi-Najafabady, S., Malhi, Y., Aragão, L.E., Anderson, L.O., Myneni, R.B. and Nemani, R. (2013) Persistent Effects of a Severe Drought on Amazonian Forest Canopy. Proceedings of the National Academy of Sciences, 110, 565-570. https://doi.org/10.1073/pnas.1204651110 
Submit or recommend next manuscript to SCIRP and we will provide best service for you:

Accepting pre-submission inquiries through Email, Facebook, LinkedIn, Twitter, etc. A wide selection of journals (inclusive of 9 subjects, more than 200 journals)

Providing 24-hour high-quality service

User-friendly online submission system

Fair and swift peer-review system

Efficient typesetting and proofreading procedure

Display of the result of downloads and visits, as well as the number of cited articles Maximum dissemination of your research work

Submit your manuscript at: http://papersubmission.scirp.org/

Or contact ajcc@scirp.org 